\title{
Cellular responses to modified Plasmodium falciparum MSP I 19 antigens in individuals previously exposed to natural malaria infection
}

\author{
Christian MF Okafor*1,5, Chiaka I Anumudu ${ }^{1}$, Yusuf O Omosun ${ }^{1,6}$, \\ Chairat Uthaipibull ${ }^{3,7}$, Idowu Ayede ${ }^{2}$, Henrietta O Awobode ${ }^{1}$, \\ Alex B Odaibo ${ }^{1}$, Jean Langhorne ${ }^{3}$, Anthony A Holder ${ }^{3}$, Roseangela I Nwuba ${ }^{1}$ \\ and Marita Troye-Blomberg 4
}

\begin{abstract}
Address: ${ }^{1}$ Cellular Parasitology Programme, Department of Zoology University of Ibadan, Ibadan, Nigeria, ${ }^{2}$ Oni Memorial Children's Hospital, Ring Road, Ibadan, Nigeria, ${ }^{3}$ Division of Parasitology, MRC National Institute for Medical Research, Mill Hill, London NW7 1AA, UK, ${ }^{4}$ Department of Immunology, Wenner-Gren Institute, Arrhenius Laboratories, Stockholm University, Stockholm, Sweden, ${ }^{5}$ College of Art and Sciences, Northwest University, 5520, 108th Ave. NE, Kirkland WA 98033, USA, 'Department of Biotechnology, Bells University of Technology, Sango-Otta, Nigeria and ${ }^{7}$ Protein-Ligand Engineering and Molecular Biology Laboratory, National Center for Genetic Engineering and Biotechnology (BIOTEC), Thailand Science Park, Pathumthani, Thailand

Email: Christian MF Okafor* - cmfokafor2001@yahoo.com; Chiaka I Anumudu - cianumudu@yahoo.com;

Yusuf O Omosun - yusufomosun@yahoo.com; Chairat Uthaipibull - chairat@biotec.or.th; Idowu Ayede - idayede@yahoo.co.uk; Henrietta O Awobode - awobodet@yahoo.com; Alex B Odaibo - abodaibo@yahoo.com; Jean Langhorne - jlangho@nimr.mrc.ac.uk; Anthony A Holder - aholder@nimr.mrc.ac.uk; Roseangela I Nwuba - rnwuba@yahoo.com; Marita Troye-Blomberg - marita@imun.su.se

* Corresponding author
\end{abstract}

Published: 23 November 2009

Malaria Journal 2009, 8:263 doi:10.1 I86/1475-2875-8-263

This article is available from: http://www.malariajournal.com/content/8/I/263

(C) 2009 Okafor et al; licensee BioMed Central Ltd.

This is an Open Access article distributed under the terms of the Creative Commons Attribution License (http://creativecommons.org/licenses/by/2.0), which permits unrestricted use, distribution, and reproduction in any medium, provided the original work is properly cited.

\begin{abstract}
Background: MSPI processing-inhibitory antibodies bind to epitopes on the $19 \mathrm{kDa}$ C-terminal region of the Plasmodium falciparum merozoite surface protein I (MSPI $\left.{ }_{19}\right)$, inhibiting erythrocyte invasion. Blocking antibodies also bind to this antigen but prevent inhibitory antibodies binding, allowing invasion to proceed. Recombinant $\mathrm{MSPI}_{19}$ had been modified previously to allow inhibitory but not blocking antibodies to continue to bind. Immunization with these modified proteins, therefore, has the potential to induce more effective protective antibodies. However, it was unclear whether the modification of $\mathrm{MSPI}_{19}$ would affect critical T-cell responses to epitopes in this antigen.
\end{abstract}

Methods: The cellular responses to wild-type $\mathrm{MSPI}_{19}$ and a panel of modified $\mathrm{MSPI}_{19}$ antigens were measured using an in-vitro assay for two groups of individuals: the first were malaria-naïve and the second had been naturally exposed to Plasmodium falciparum infection. The cellular responses to the modified proteins were examined using cells from malaria-exposed infants and adults.

Results: Interestingly, stimulation indices (SI) for responses induced by some of the modified proteins were at least two-fold higher than those elicited by the wild-type $\mathrm{MSPI}_{19}$. A protein with four amino acid substitutions (Glu27 $\rightarrow$ Tyr, Leu3I $\rightarrow$ Arg, Tyr34 $\rightarrow$ Ser and Glu43 $\rightarrow$ Leu) had the highest stimulation index (SI up to 360) and induced large responses in $64 \%$ of the samples that had significant cellular responses to the modified proteins. 
Conclusion: This study suggests that specific $\mathrm{MSPI}_{19}$ variants that have been engineered to improve their antigenicity for inhibitory antibodies, retain T-cell epitopes and the ability to induce cellular responses. These proteins are candidates for the development of MSPI-based malaria vaccines.

\section{Background}

The development of an effective malaria vaccine remains a major public health challenge. Merozoite surface protein (MSP)-1 of Plasmodium falciparum is being developed as a vaccine candidate to protect against the erythrocytic stages of the malaria parasite $[1,2]$. Much of the work has been focused on the $19 \mathrm{kDa}$ C-terminal region of MSP1 (called $\mathrm{MSP}_{19}[3]$ ). Protection against challenge infection following immunization in rodent and monkey models of malaria has been reported [4-11]. However, sero-epidemiological studies [12-16] and vaccine trials [17] in human populations have given conflicting results concerning the protective role of anti-MSP1 antibodies, which may be explained by differences in the fine specificities of the $M S P 1_{19}$-specific antibodies $[18,19]$. It can be concluded from these studies that in the humoral control of malaria infection, the fine specificity of the antibody response may be crucial to inhibit erythrocyte invasion by merozoites.

The MSP1 precursor is cleaved into four fragments on the merozoite surface and at invasion the C-terminal $42 \mathrm{kDa}$ fragment $\left(\mathrm{MSP}_{42}\right)$ is processed further into two smaller fragments: a $33 \mathrm{kDa}$ polypeptide $\left(\mathrm{MSP}_{33}\right)$ and the C-terminal MSP $1_{19}$, which remains on the parasite surface during invasion of red blood cells (RBC). MSP1 has been reported to elicit three types of antibody that can bind $\mathrm{MSP}_{42}[2,20,21]$. These are a) inhibitory antibodies, which inhibit the cleavage of $\mathrm{MSP}_{42}$ and thus invasion of RBC; b) blocking antibodies, which have overlapping specificities and compete with inhibitory antibodies for binding to the antigen, thereby allowing processing and invasion to occur even in the presence of inhibitory antibodies; and c) neutral antibodies that are neither inhibitory nor blocking. Significantly, it has been shown that all these types of MSP1 $1_{19}$-specific antibodies are part of the natural immune response to MSP1 in malaria-exposed individuals $[22,23]$. Thus, the rational design of an MSP1based malaria vaccine for the preferential induction of processing-inhibitory antibodies with the appropriate specificities is an important goal. The relative abundance of these protective antibodies in relation to the detrimental (blocking) antibodies in any infection is one of the important factors that may determine the outcome of that infection $[2,3,20,22]$.
The $\mathrm{MSP}_{19}$ epitopes recognized by inhibitory and blocking monoclonal antibodies (mAbs) have been mapped using site-directed mutagenesis, PEPSCAN, and nuclear magnetic resonance (NMR) $[21,24,25]$. A number of single and multiple amino acid substitutions in $\mathrm{MSP}_{19}$ has been made, which had either no effect, or reduced, or completely abolished the binding of individual mAbs [21]. Recent data have shown that polyclonal antibodies in sera obtained from individuals living in a malaria endemic area recognize and bind to the modified antigens $[22,23]$. A vaccine based on one of these modified proteins could be designed to induce inhibitory but not blocking Abs and thus provide a focused polyclonal antibody response to inhibit $\mathrm{RBC}$ invasion and cleavage of MSP1 [21,22].

CD4+ T-cell responses, providing help for MSP1-specific B-cell responses, are essential for protective immunity in rodent models of malaria, in protective immunity induced by immunization with $\mathrm{MSP}_{19}[26]$. Since it is possible that the amino acid substitutions may alter the pattern and kinetics of $\mathrm{MSP}_{19}$ antigen processing of within the MHC class II pathway, and thus the peptides presented, it will be important to determine whether the variant MSP1 molecules are recognized by immune cells obtained from individuals naturally primed by malaria infection. Some reports have suggested that T-cell responses to MSP1 in malaria-exposed donors are poor $[27,28]$, possibly because of the difficulty in processing the highly disulfide bonded globular MSP1 $19[27,29,30]$. Also, the common occurrence of high background responses in both unexposed and exposed donors makes it difficult to demonstrate T-cell responses in field samples. The study described here was carried out to determine whether modified MSP $1_{19}$ antigens were recognized by immune cells from naturally exposed and immune individuals living in a malaria endemic area, and whether modification of the critical T cell epitopes of MSP1 19 would enhance or compromise cellular responses. Results from this study show that variant $M S P 1_{19}$ with two or more amino acid substitutions not only stimulated PBMC from exposed individuals but also induced proliferative responses in vitro of greater magnitude than the wild-type (WT) antigen. These results suggest that these modified MSP1 proteins may be suitable candidates for a malaria 
vaccine that would induce both protective antibodies and suitable cellular responses.

\section{Methods}

\section{Subjects and samples}

Volunteers were recruited in Ibadan, Nigeria where P. falciparum malaria is perennial. High malaria transmission occurs from April to November, corresponding to the rainy season (March to October), all samples were collected in March. The study protocol was reviewed and approved by the Joint University of Ibadan/University College Hospital Ethical committee. Informed consent was obtained from all participating individuals or legal guardians of children enrolled in the study. The donors were divided into two groups; the first was between three months and seven years of age (six individuals) and had clinical malaria symptoms, while the second aged between 13 yrs and 43 yrs (30 individuals) was without clinical malaria at recruitment. Venous blood (up to $4 \mathrm{ml}$ from children and $7 \mathrm{ml}$ from adults) was collected in heparinized tubes and transported immediately in insulated boxes to the laboratory for processing at the Department of Immunology, Wenner-Gren Institute, Stockholm University, Sweden. Giemsa-stained thick-blood films were examined for the presence of malaria parasites. A group of seven malaria-unexposed European donors provided control samples for the study.

\section{Peripheral blood mononuclear cells (PBMC)}

Human PBMC were harvested from whole blood approximately 24 hrs after phlebotomy. PBMC were prepared by Ficoll-Hypaque (Pharmacia, Uppsala, Sweden) density gradient centrifugation according to the manufacturers' instructions. The harvested cells were suspended in freezing medium [ $10 \%$ dimethyl sulfoxide (DMSO), 20\% fetal calf serum (FCS), RPMI 1640, HEPES and L-glutamine], frozen at $1{ }^{\circ} \mathrm{C} \mathrm{min}^{-1}$ to $-70^{\circ} \mathrm{C}$ in plastic containers (Nalgene Cryo, Nalge Company, USA), and then transferred into liquid nitrogen until used in in vitro assays. The cells had a demonstrated $>95 \%$ viability when compared with frozen cells collected in Sweden.

\section{Antigens}

Cells in the proliferation assays were stimulated by antigens at a predetermined final concentration of $1 \mu \mathrm{g} / \mathrm{ml}$.

\section{Wild-type (WT) and modified MSPI proteins}

The recombinant wild-type and modified $\mathrm{MSP}_{19}$ antigens fused to Schistosoma japonicum glutathione S-transferase (GST) have been described previously [21]. Table 1 shows the specific modifications in the primary sequence of the MSP $1_{19}$ antigens used; residues are numbered from the $\mathrm{N}$-terminus of $\mathrm{MSP} 1_{19}$.
Table I: The panel of modified $\mathrm{MSPI}_{19}$ antigens

\begin{tabular}{lll}
\hline \multicolumn{2}{l}{ Amino acid substitutions in the primary sequence } \\
\hline Position(s) & Wildtype residue & Variant residue \\
\hline Single amino acid & & \\
\hline 6 & Gln & Ile \\
\hline 14 & Gln & Arg \\
\hline 32 & Leu & Arg \\
\hline 33 & Asn & Ile \\
\hline 40 & Lys & Ile \\
\hline
\end{tabular}

Multiple amino acids

\begin{tabular}{lll}
\hline $12+28$ & Cys+Cys & lle+Trp \\
\hline $34+39$ & Tyr+Asp & Ser+Thr \\
\hline $43+48$ & Glu+Thr & Leu+Lys \\
\hline $15+27+31+43$ & Asn+Glu+Leu+Glu & Arg+Tyr+Arg+Leu \\
\hline $27+31+34+43$ & Glu+Leu+Tyr+Glu & Tyr+Arg+Ser+Leu \\
\hline
\end{tabular}

Position in the sequence is numbered from the $\mathrm{N}$-terminus of $\mathrm{MSPI}_{19}$

\section{P. falciparum antigen}

Crude P. falciparum antigen (F32) was used as a positive control for confirming previous infection or lack of exposure to $P$. falciparum in exposed and naïve individuals [31].

\section{Control antigens}

Phytohemagglutinin (PHA; Sigma, Poole, UK) was used as positive control for testing lymphocyte viability and responsiveness. Recombinant GST was used as a control antigen.

\section{Cell proliferation assays}

Frozen PBMCs were thawed, washed three times, and resuspended at a final concentration of $10^{6}$ viable cells $/ \mathrm{ml}$ in complete medium [RPMI 1640 containing $2 \mathrm{mM} \mathrm{L}$ glutamine, $50 \mathrm{U} / \mathrm{ml}$ penicillin, $0.1 \mathrm{mg} / \mathrm{ml}$ streptomycin, $10 \mathrm{mM}$ HEPES, $0.22 \%$ (vol $/ \mathrm{vol}$ ) sodium bicarbonate and $10 \%$ heat-inactivated non-immune FCS]. The cells were then plated into sterile, round-bottomed 96-well microtiter plates at $10^{5}$ viable cells/well in $100 \mu$ l culture medium. Antigens were diluted to $2 \mu \mathrm{g} / \mathrm{ml}$ in complete medium and $100 \mu \mathrm{l}$ of the antigen solution added to the wells containing the cells (in triplicates), giving a final 
antigen concentration of $1 \mu \mathrm{g} / \mathrm{ml}$. Unstimulated cultures served as negative controls, and those stimulated with PHA as positive controls. The plates were incubated at $37^{\circ} \mathrm{C}$ in a humidified atmosphere containing $5 \% \mathrm{CO}_{2}$ for 6 days. On the $5^{\text {th }}$ day of incubation, $100 \mu$ of supernatant were removed from each well and replaced with 100 $\mu \mathrm{l}$ of fresh medium containing $\left[{ }^{3} \mathrm{H}\right]$ thymidine $(1 \mu \mathrm{Ci} /$ well; Amersham Life Sciences, Little Chalfont, UK) for a further 16-18 hours. Cells were harvested onto filter mats using a cell harvester (Tomtec) and incorporation of radioactivity was measured using a Microbeta counter. Proliferative responses expressed as the geometric mean of radioactivity incorporation in counts per minute were determined for each antigen, and the stimulation index (SI) was calculated as the ratio of incorporation by antigen-stimulated cells to that of the unstimulated control cells. Subjects whose cells responded to one or more vari- ants with a SI two-fold or more above that of the GST control were grouped as responders whereas others with a SI similar to or lower than that of GST were not considered to be responders. This cut-off was set to ensure that we were measuring a response to $\mathrm{MSP} 1_{19}$ and not GST.

\section{Statistics}

Correlation coefficients and stimulation indices were plotted using SPSS and MS Excel software ( $p=0.05$ was considered significant).

\section{Results}

\section{Parasitemia of donors}

Microscopic examination of blood smears from the 36 donors in this study showed that $20(56 \%)$ were positive for $P$. falciparum, while no parasites were detected in the blood of the remaining donors. Parasite burden in indi-

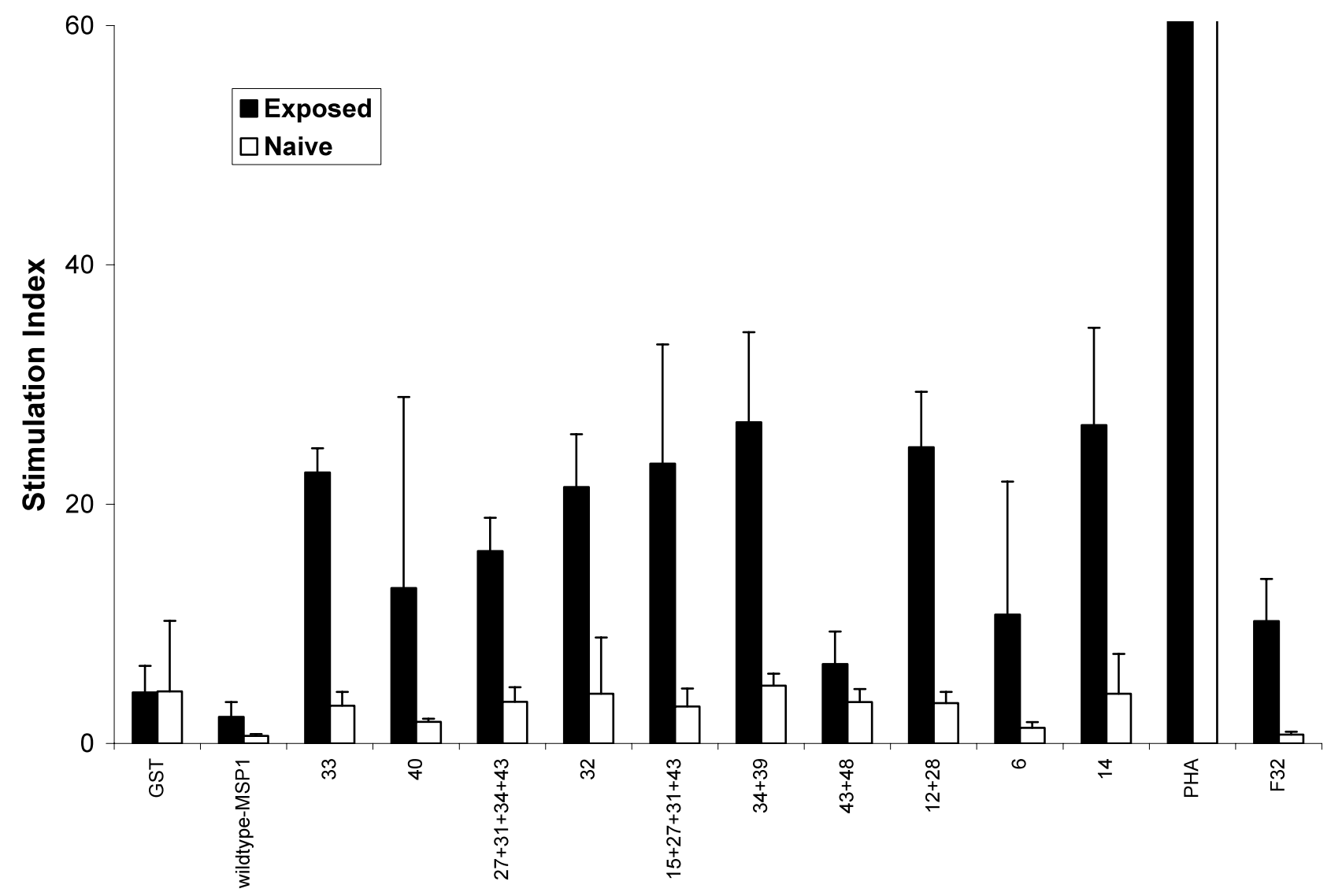

Antigens

Figure I

Mean $\mathbf{T}$ cell responses in malaria-exposed and un-exposed individuals. Responses to the wildtype-MSPI 19 , modified $\mathrm{MSPI}_{19}$ antigens, PHA, GST and F32 (a crude malarial antigen preparation) in seven malaria-exposed individuals (shaded boxes) and five unexposed malaria-naïve individuals (open boxes), as measured by stimulation index (SI). The malaria-exposed individuals showed significantly higher responses to all the malaria antigens than the malaria-unexposed individuals $(P=0.00 \mathrm{I})$. 
viduals decreased significantly with increasing age among the subjects ( $p=0.021)$. Among the parasitemic subjects, 6 of 20 were symptomatic at the time of recruitment with parasite densities ranging between 280 and 72,727 parasites/ $\mu$ l blood, while the remaining 14 donors who were asymptomatic had a parasitemia that ranged between 40 and 600 parasites $/ \mu$ l blood (data not shown).

\section{Cellular proliferation in response to the wild-type and modified $\mathrm{MSPI}_{19}$ antigens}

The stimulatory capacity of each antigen in the panel was assessed. In vitro cellular responses to the WT MSP $1_{19}$ and a panel of ten variants with one or more amino acid substitution [21] (Table 1) were studied, using PBMC from the 36 naturally exposed and 7 malaria-naïve donors. Proliferative responses to both the WT and the modified antigens were observed and a stimulation index was calculated for each. Though not all the malaria-exposed donors responded to both WT and modified antigens, these individuals had significantly higher proliferative responses than the malaria naïve group (Figure 1). In addition, for the malaria-exposed individuals, it was observed that most of the responses to the modified $\mathrm{MSP}_{19}$ antigens were significantly greater than the response to the WT molecule.

Cells from 14 (39\%) of the exposed individuals had a significant proliferative response to the panel of $\mathrm{MSP}_{19}$ antigens (SI range $>2-360$ ). These individual were grouped as responders, while the remaining $61 \%$ of malaria-exposed donors that responded poorly to the antigens were grouped as non-responders. A modified protein, $27+31+34+43$ with four amino acid substitutions (Table 1 ), had the most intense and consistently highest T-cell stimulatory effect, with a mean SI as high as 360 and elicited a response in the greatest number of donors: nine of

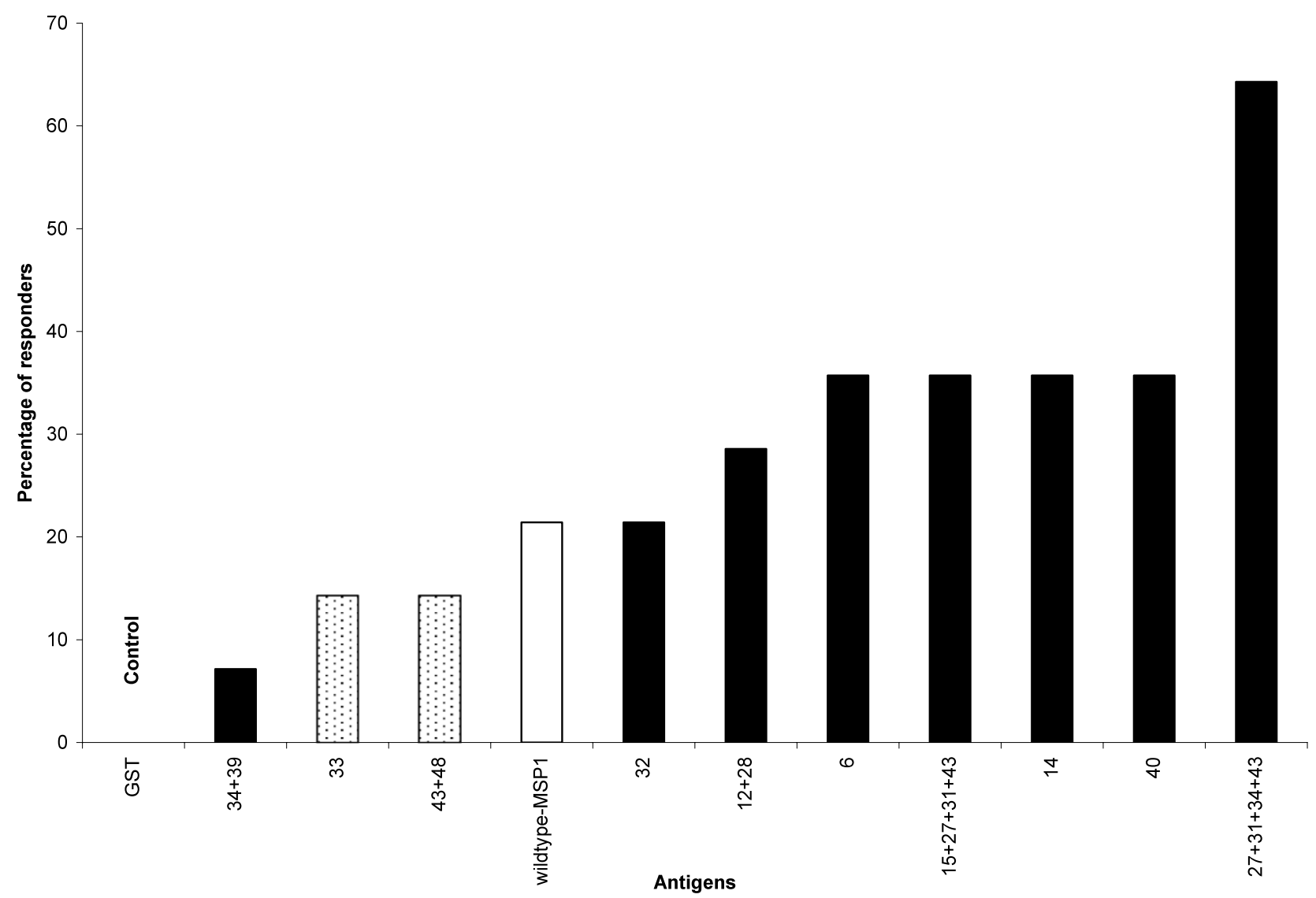

Figure 2

Prevalence of response to MSP I 19 variant and wildtype antigens. Prevalence of T cell responses to the antigens for I4 individuals that were identified as high responders. The observed responses to the variants (shaded bars) were significantly higher than the response to the WT-MSPI ${ }_{19}$ (open bar). The responses to the variants $43+48$ and 33 were higher than that to the GST-control but lower than that to WT-MSPI 19 . 
$14(64 \%)$ responders had a significant response to this variant (Figure 2). In these same nine individuals, the responses to the $27+31+34+43$ variant were significantly higher than the responses to the wild-type (WT-MSP $1_{19}$ ) antigen. Using cells collected from the same individual the SI was 240-fold greater than the SI seen in response to WT-MSP1. More than half of the nine (5/9) individuals that responded to the $27+31+34+43$ variant had a SI that was at least five-fold higher than that seen in response to the wild-type antigen.

Three single amino acid substitution variants 6,14 and 40 (Table 1) and the $15+27+31+43$ variant (a four-residue substitution variant) all elicited high responses in 5/14 $(36 \%)$ of the responders (Figure 2). Four of $14(27 \%)$ responders had a significant response to the $12+28$ variant which lacks a disulfide bond (Cys12 $\rightarrow$ Ile and Cys28 $\rightarrow$ Trp). The 34+39 variant (Tyr34 $\rightarrow$ Ser, Asp39 $\rightarrow$ Thr) elicited a response in only one of the responders. Two of the $14(14 \%)$ responders had responses to the 33 (Asn33 $\rightarrow$ Ile) and 43+48 (Glu43 $\rightarrow$ Leu and Thr $48 \rightarrow$ Lys) variants; the intensity of these responses were higher than the responses to the GST control protein but lower than the responses to WT-MSP $1_{19}$.

Intense responses were also elicited by the $15+27+31+43$ variant in five of the responders with a mean SI of 314.6. Three out of six individuals that responded to $15+27+31+43$ had a SI that was at least five-fold greater than that to the wild-type protein. Variants 14 and $12+28$ induced a mean SI of 315.7 and 269, respectively. The data revealed that all the high stimulation indices (SI $>100$ ), occurred with the MSP $1_{19}$ variants containing two or more amino acid substitutions except for the variant 14 which had a single amino acid change of Gln to Arg at position 14. All the variants in the panel that induced an intense response consistently induced $a \geq 3$-fold stronger response than the WT protein.

The difference between the two 4 -amino acid substitution variants, $27+31+34+43$ and $15+27+31+43$ is a substitution Asn $15 \rightarrow$ Arg in $15+27+31+43$ and Tyr34 $\rightarrow$ Ser in

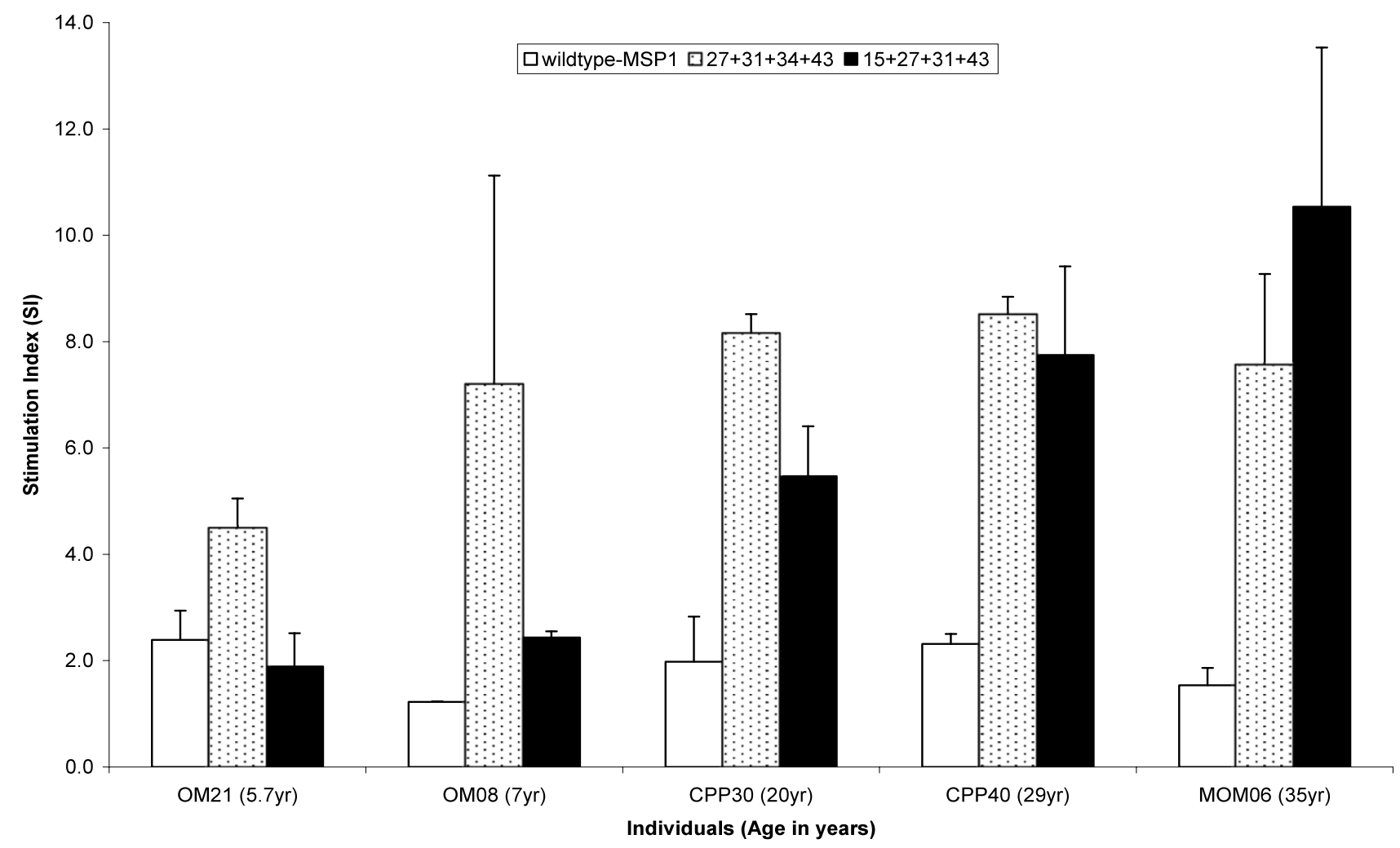

Figure 3

Cellular responses to wildtype-MSPI ${ }_{19}$ antigen and the two variants with four amino acid substitutions. $27+3 I+34+43$ and $15+27+3 I+43 \mathrm{MSPI}_{19}$ variants in 5 individuals of different ages and malaria exposure. OM2I and OM08 had clinical presentation but the others did not. The stimulation indices (SI) for the $27+3 I+34+43$ (dotted boxes) and $|5+27+3|+43$ (shaded box) variants were significantly higher than the SI for the WT-MSPI 19 antigen (clear boxes). 
$27+31+34+43$. The responses to these two variants were compared in five individuals that responded to both variants (Figure 3). For this small group, the data suggested that the $27+31+34+43$ variant preferentially induced a response in cells obtained from children whereas $15+27+31+43$ had a greater effect with cells from adults. The response to the WT antigen did not change significantly with increasing age (Figure 3 ).

\section{Discussion}

This study investigated the proliferative cellular responses to wild-type MSP $1_{19}$ and several variant proteins in individuals naturally exposed to the $P$. falciparum parasite. The results revealed that the modified $M S P 1_{19}$ antigens induced stronger and more frequent responses as compared to the wild type MSP1. In particular, the responses seen to most of the modified antigens with two or more amino acid substitutions were stronger than the response to the native antigen. These findings indicate that the antigenic epitopes in some of the $M S P 1_{19}$ variants were not compromised by the specific amino acid modifications; some of these modifications actually enhanced the response to the proteins.

The MSP- $1_{19}$ sequence is highly conserved, largely with diversity at only four positions in its 96 amino acid residues [32]. This study has shown that selective replacement of up to four amino acid residues in the MSP $1_{19}$ sequence did not compromise the linear epitopes that are recognized by T-cells.

In the population tested, a response to one or more variants was noted in $38 \%$ of individuals, whereas only $22 \%$ had a proliferative response to $\mathrm{WT}-\mathrm{MSP}_{19}$. In previous work to evaluate human T-cell responses to WT-MSP1 19 antigen a prevalence of $26 \%$ responders was observed in Gambian and Kenyan populations, with marked individual variations $[27,28]$.

The higher prevalence of cellular proliferative responses to the modified $\mathrm{MSP}_{19}$ noted in this study might be explained by structural changes induced by the modifications. It has been suggested that the relatively poor cellular response to $\mathrm{MSP}_{19}$ is due to its structural complexity and resistance to proteases. Thus with 6 disulfide bonds it is impossible to load MSP $1_{19}$ onto MHC class II molecules and it can only be available for loading when the bonds have been reduced $[29,30]$. A form of MSP $1_{19}$ that is more accessible to proteases would allow improved processing by antigen-presenting cells (APC), which could enhance the cellular responses and thus vaccine efficacy [29].

Human PBMC recognized and responded significantly to eight out of ten variants, which had been designed to either reduce or abolish the binding of known blocking
mAbs [21] (Figure 1). Among those individuals whose cells responded, the prevalence of the responses to each variant ranged from $7 \%$ to $64 \%$ of the population. More people responded to the $27+31+34+43$ variant than any of the other variants tested (Figure 2). The ability of the cells to respond to more than one variant was age dependent, thus cells from adults responded to more variants than the cells from children. This suggests a possible role of previous and repeated exposure to infection in the breadth of recognition and response to these variants (Figure 3).

The two mutant proteins with four amino acid substitutions designated $27+31+34+43$ and $15+27+31+43$, characterized as having epitopes for MSP1-processing inhibitory antibodies, but no binding affinity for known blocking mAbs [21] were the most frequently recognized and they induced some of strongest cell responses observed. The $27+31+34+43$ mutant induced the strongest proliferative response (SI up to 360) and was the antigen most frequently recognized by cells from malariaexposed adults and children. Each individual that responded to the $15+27+31+43$ variant also responded either with equal or greater intensity to the $27+31+34+43$ variant, suggesting a better recognition of the $27+31+34+43$ variant by the responding cells. This is attributable to the Tyr34 $\rightarrow$ Ser modification in the $27+31+34+43 \quad \mathrm{MSP}_{19}$ variant compared with the Asn $15 \rightarrow$ Arg substitution in the $15+27+31+43$ variant. This result is consistent with the suggested role of Tyr34 at the interface between the two epidermal-growth factor (EGF) domains in providing structural stability; the replacement of tyrosine by serine may result in an antigen that can be processed more readily. From these results, and the earlier antigenicity studies, the $27+31+34+43$ MSP1 ${ }_{19}$ variant would be a favored variant for development of a MSP1-based vaccine. However, additional studies are needed to determine whether the difference in the cellular responses to these two closely related proteins is a result of recognition by individual cell types (host factors) or a result of the structural perturbations due to the amino acid substitutions in the MSP1 sequence.

\section{Conclusion}

This study provides a possible basis to support the use of the $27+31+34+43$ and $15+27+31+43 \mathrm{MSP}_{19}$ proteins as engineered immunogens to induce improved cellular responses and provide the T-cell help for the production of protective MSP1 processing-inhibitory antibodies. Unlike the wild-type MSP1 ${ }_{19}$ protein it is expected that these proteins will not induce blocking antibody specificities. However, there is a need to carry out more detailed studies of cellular responses to $M S P 1_{19}$ variants with a larger sample size. In order to understand the importance of these modifications in antigen presentation, it would 
be useful to properly characterize the phenotypes of the proliferating cells. In addition the role of individual host genetics, and other factors in the modulation of cellular responses to these variants cannot be overemphasized. The potential in vitro correlates of protective immunity defined in this study represent an important step forward in the search for and evaluation of an efficient MSP1based malaria vaccine.

\section{Abbreviations}

GST: glutathione S-transferase; MSP: merozoite surface protein; PBMC: peripheral blood mononuclear cells; RBC: red blood cell; SI: stimulation index; WT: wildtype.

\section{Competing interests}

The authors declare that they have no competing interests.

\section{Authors' contributions}

CMFO, CIA, RIN, MTB AAH, CU, IA and JL made substantial contributions to the conception and the design of the study, or acquisition, analysis and interpretation of data; YOO, HOA and $\mathrm{ABO}$ were involved in drafting the manuscript or revising it critically for content; and RIN, JL, AAH and $\mathrm{MTB}$, gave final approval of the version to be published.

\section{Acknowledgements}

The authors do not have a commercial or other association that might pose a conflict of interest. Financial support was provided by the Swedish Agency for Research Development with Developing Countries (SIDA/SAREC), the European Commission through contract LSHP-CT-2004-503578 and the EUROMALVAC Consortium Contract QLK2-CT-2002-0I I 97; the Medical Research Council, UK; and the Multilateral Initiative on Malaria (MIM) project grant (AI058I) to Dr. RI Nwuba through the UNICEF/UNDPI World Bank/WHO Programme for Research and Training in Tropical Diseases (TDR). CMF Okafor was a recipient of MIMPAC Network Exchange Programme scholarship and C. Uthaipibull was a recipient of a Thai Government Scholarship. We acknowledge with appreciation, the cooperation of the individuals and parents who gave consent for their children to participate in the study. We also acknowledge the contributions of Femi lbrahim, K. Akpala and Salah Eldin to this work.

\section{References}

I. Angov E, Aufiero BM, Turgeon AM, Van Handenhove M, Ockenhouse CF, Kester KE, Walsh DS, McBride JS, Dubois MC, Cohen J, et al:: Development and pre-clinical analysis of a Plasmodium falciparum Merozoite Surface Protein- I (42) malaria vaccine. Mol Biochem Parasitol 2003, I 28: 1 95-204.

2. Holder AA, Guevara Patino JA, Uthaipibull C, Syed SE, Ling IT, ScottFinnigan T, Blackman MJ: Merozoite surface protein I, immune evasion, and vaccines against asexual blood stage malaria. Parassitologia 1999, 41:409-4|4.

3. Holder $A A$ : The carboxy-terminus of merozoite surface protein I: structure, specific antibodies and immunity to malaria. Parasitology 2009, I 36: 1445-|1456.

4. Chang SP, Case SE, Gosnell WL, Hashimoto A, Kramer KJ, Tam LQ, Hashiro CQ, Nikaido CM, Gibson $\mathrm{HL}$, Lee- $\mathrm{Ng} C \mathrm{CT}$, et al.: A recombinant baculovirus 42-kilodalton C-terminal fragment of Plasmodium falciparum merozoite surface protein I protects Aotus monkeys against malaria. Infect Immun 1996, 64:253-26I.

5. Daly TM, Long CA: A recombinant 15-kilodalton carboxyl-terminal fragment of Plasmodium yoelii yoelii I7XL merozoite surface protein I induces a protective immune response in mice. Infect Immun 1993, 61:2462-2467.

6. Hirunpetcharat C, Tian JH, Kaslow DC, van Rooijen N, Kumar S, Berzofsky JA, Miller LH, Good MF: Complete protective immunity induced in mice by immunization with the 19-kilodalton carboxyl-terminal fragment of the merozoite surface protein-I (MSP I [19]) of Plasmodium yoelii expressed in Saccharomyces cerevisiae: correlation of protection with antigen-specific antibody titer, but not with effector CD4+ T cells. J Immunol 1997, 159:3400-34II.

7. Kumar S, Collins W, Egan A, Yadava A, Garraud O, Blackman MJ, Guevara Patino JA, Diggs C, Kaslow DC: Immunogenicity and efficacy in aotus monkeys of four recombinant Plasmodium falciparum vaccines in multiple adjuvant formulations based on the I9-kilodalton $\mathbf{C}$ terminus of merozoite surface protein I. Infect Immun 2000, 68:22 I 5-2223.

8. Ling IT, Ogun SA, Holder AA: Immunization against malaria with a recombinant protein. Parasite Immunol 1994, 16:63-67.

9. Singh S, Kennedy MC, Long CA, Saul AJ, Miller LH, Stowers AW: Biochemical and immunological characterization of bacterially expressed and refolded Plasmodium falciparum 42-kilodalton C-terminal merozoite surface protein I. Infect Immun 2003, 71:6766-6774.

10. Stowers AW, Chen Lh LH, Zhang Y, Kennedy MC, Zou L, Lambert L, Rice TJ, Kaslow DC, Saul A, Long CA, et al.: A recombinant vaccine expressed in the milk of transgenic mice protects Aotus monkeys from a lethal challenge with Plasmodium falciparum. Proc Natl Acad Sci USA 2002, 99:339-344.

11. Stowers AW, Cioce V, Shimp RL, Lawson M, Hui G, Muratova O, Kaslow DC, Robinson R, Long CA, Miller LH: Efficacy of two alternate vaccines based on Plasmodium falciparum merozoite surface protein $I$ in an Aotus challenge trial. Infect Immun 200I, 69:1536-1546.

12. Dodoo D, Aikins A, Kusi KA, Lamptey H, Remarque E, Milligan P, Bosomprah S, Chilengi R, Osei YD, Akanmori BD, et al.: Cohort study of the association of antibody levels to AMA I, MSP I ${ }_{19}, \mathrm{MSP}_{3}$ and GLURP with protection from clinical malaria in Ghanaian children. Malar J 2008, 7:142.

13. Braga EM, Barros RM, Reis TA, Fontes CJ, Morais CG, Martins MS, Krettli AU: Association of the IgG response to Plasmodium falciparum merozoite protein (C-terminal 19 kD) with clinical immunity to malaria in the Brazilian Amazon region. $\mathrm{Am} J$ Trop Med Hyg 2002, 66:46I-466.

14. Dodoo D, Theander TG, Kurtzhals JA, Koram K, Riley E, Akanmori $B D$, Nkrumah FK, Hviid L: Levels of antibody to conserved parts of Plasmodium falciparum merozoite surface protein $I$ in Ghanaian children are not associated with protection from clinical malaria. Infect Immun 1999, 67:2131-2/37.

15. Egan AF, Morris J, Barnish G, Allen S, Greenwood BM, Kaslow DC, Holder AA, Riley EM: Clinical immunity to Plasmodium falciparum malaria is associated with serum antibodies to the 19$\mathrm{kDa}$ C-terminal fragment of the merozoite surface antigen, PfMSP-I. J Infect Dis 1996, 173:765-769.

16. Tolle R, Fruh K, Doumbo O, Koita O, N'Diaye M, Fischer A, Dietz K, Bujard $H$ : A prospective study of the association between the human humoral immune response to Plasmodium falciparum blood stage antigen gp 190 and control of malarial infections. Infect Immun 1993, 61:40-47.

17. Ogutu BR, Apollo OJ, McKinney D, Okoth W, Siangla J, Dubovsky F, Tucker K, Waitumbi JN, Diggs C, Wittes J, et al:: Blood stage malaria vaccine eliciting high antigen-specific antibody concentrations confers no protection to young children in Western Kenya. PLoS One 2009, 4:e4708.

18. Corran PH, O'Donnell RA, Todd J, Uthaipibull C, Holder AA, Crabb $B S$, Riley EM: The fine specificity, but not the invasion inhibitory activity, of 19-kilodalton merozoite surface protein Ispecific antibodies is associated with resistance to malarial parasitemia in a cross-sectional survey in The Gambia. Infect Immun 2004, 72:6185-6189.

19. Okech BA, Corran PH, Todd J, Joynson-Hicks A, Uthaipibull C Egwang TG, Holder AA, Riley EM: Fine specificity of serum antibodies to Plasmodium falciparum merozoite surface protein, PfMSP-I(19), predicts protection from malaria infection and high-density parasitemia. Infect Immun 2004, 72: I557-I 567.

20. Guevara Patino JA, Holder AA, McBride JS, Blackman MJ: Antibodies that inhibit malaria merozoite surface protein-I processing 
and erythrocyte invasion are blocked by naturally acquired human antibodies. J Exp Med 1997, 186:1689-1699.

21. Uthaipibull C, Aufiero B, Syed SE, Hansen B, Guevara Patino JA, Angov E, Ling IT, Fegeding K, Morgan WD, Ockenhouse C, et al.: Inhibitory and blocking monoclonal antibody epitopes on merozoite surface protein I of the malaria parasite Plasmodium falciparum. J Mol Biol 200I, 307: I38I-I394.

22. Nwuba RI, Sodeinde $\mathrm{O}$, Anumudu $\mathrm{Cl}$, Omosun $\mathrm{YO}$, Odaibo $\mathrm{AB}$, Holder AA, Nwagwu M: The human immune response to Plasmodium falciparum includes both antibodies that inhibit merozoite surface protein I secondary processing and blocking antibodies. Infect Immun 2002, 70:5328-533I.

23. Omosun $Y O$, Adoro $S$, Anumudu $C l$, Odaibo $A B$, Uthiapibull $C$ Holder AA, Nwagwu M, Nwuba RI: Antibody specificities of children living in a malaria endemic area to inhibitory and blocking epitopes on MSP-I $I_{19}$ of Plasmodium falciparum. Acta Trop 2009, 109:208-2/2.

24. Dekker C, Uthaipibull C, Calder LJ, Lock M, Grainger M, Morgan WD, Dodson GG, Holder AA: Inhibitory and neutral antibodies to Plasmodium falciparum MSPI 19 form ring structures with their antigen. Mol Biochem Parasitol 2004, I 37: | 43-I49.

25. Morgan WD, Frenkiel TA, Lock MJ, Grainger M, Holder AA: Precise epitope mapping of malaria parasite inhibitory antibodies by TROSY NMR cross-saturation. Biochemistry 2005, 44:5|8-523.

26. Hirunpetcharat C, Vukovic P, Liu XQ, Kaslow DC, Miller LH, Good MF: Absolute requirement for an active immune response involving B cells and Th cells in immunity to Plasmodium yoelii passively acquired with antibodies to the 19-kDa carboxylterminal fragment of merozoite surface protein-I. J Immunol 1999, 162:7309-73|4.

27. Egan A, Waterfall M, Pinder M, Holder A, Riley E: Characterization of human T- and B-cell epitopes in the C terminus of Plasmodium falciparum merozoite surface protein I: evidence for poor T-cell recognition of polypeptides with numerous disulfide bonds. Infect Immun 1997, 65:3024-303I.

28. Udhayakumar V, Anyona D, Kariuki S, Shi YP, Bloland PB, Branch OH, Weiss W, Nahlen BL, Kaslow DC, Lal AA: Identification of $\mathbf{T}$ and $B$ cell epitopes recognized by humans in the C-terminal 42 kDa domain of the Plasmodium falciparum merozoite surface protein (MSP)-I. J Immunol 1995, I 54:6022-6030.

29. Hensmann M, Li C, Moss C, Lindo V, Greer F, Watts C, Ogun SA, Holder AA, Langhorne J: Disulfide bonds in merozoite surface protein I of the malaria parasite impede efficient antigen processing and affect the in vivo antibody response. Eur J Immunol 2004, 34:639-648.

30. Quin SJ, Langhorne J: Different regions of the malaria merozoite surface protein I of Plasmodium chabaudi elicit distinct T-cell and antibody isotype responses. Infect Immun 200I, 69:2245-225।.

31. Troye-Blomberg M, Perlmann H, Patarroyo ME, Perlmann P: Regulation of the immune response in Plasmodium falciparum malaria. II. Antigen specific proliferative responses in vitro. Clin Exp Immunol I 983, 53:345-353.

32. Miller LH, Roberts T, Shahabuddin M, McCutchan TF: Analysis of sequence diversity in the Plasmodium falciparum merozoite surface protein-I (MSP-I). Mol Biochem Parasitol 1993, 59: I-I4.

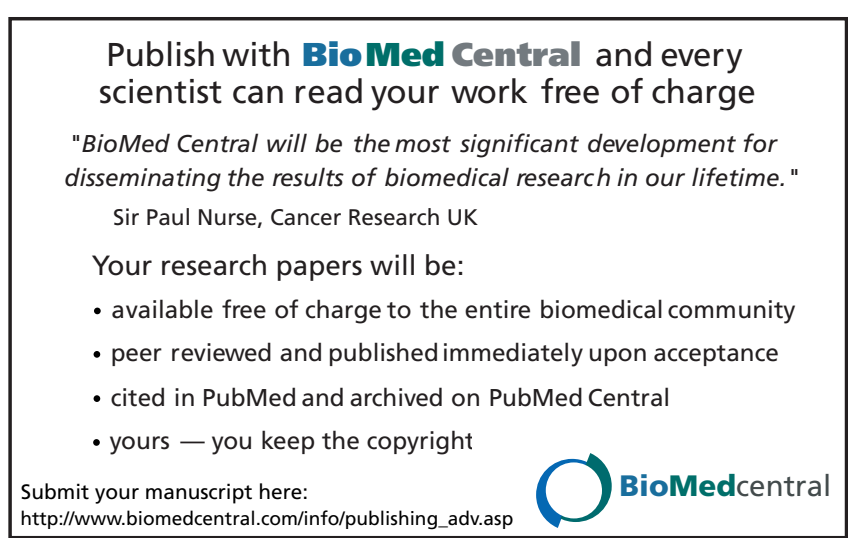

